Journal of Clinical Investigation

Vol. 42, No. 7, 1963

\title{
ANGIOTENSIN II, NOREPINEPHRINE, AND RENAL TRANSPORT OF ELECTROLYTES AND WATER IN NORMAL MAN AND IN CIRRHOSIS WITH ASCITES *
}

\author{
By JOHN H. LARAGH, PAUL J. CANNON, $\dagger$ CARL J. BENTZEL, ALFRED M. \\ SICINSKI, + AND JAY I. MELTZER
}

(From the Department of Medicine, College of Physicians \& Surgeons, Columbia University, and the Presbyterian Hospital, New York, N. Y.)

(Submitted for publication December 21, 1962; accepted March 28, 1963)

In normal subjects, the rate of aldosterone secretion fluctuates widely according to the state of salt and water balance, but the pathways mediating this relationship are still to be identified. Hypersecretion of aldosterone occurs in malignant nephrosclerosis (2). Angiotensin, the pressor peptide released from plasma by renin, increases both the adrenal secretion (3) and the urinary excretion (4) of aldosterone in man. These observations support the suggestion (5) that a renaladrenal interaction might be involved in the normal regulation of sodium and potassium balance. By this mechanism, the kidney, perhaps sensitive to diminished arterial filling or ischemia, secretes renin, generating angiotensin, which then stimulates aldosterone secretion. Aldosterone, in turn, restores renal perfusion by promoting sodium and water retention.

In malignant hypertension this mechanism may become deranged, leading to the coexistence of increased amounts of both angiotensin and aldosterone in the blood, a possibility that derives additional support from the earlier report (6) of increased blood angiotensin in these patients. On the other hand, since neither renin nor angiotensin has been conclusively demonstrated in normal human plasma, elaboration of these substances in malignant hypertension might be simply a consequence of severe renal damage.

Our more recent work has investigated the possibility that this renal-adrenal interaction participates in normal homeostasis, as well as in the

* This report was presented in part at the 54th annual meeting of the American Society for Clinical Investigation, Atlantic City, N. J., April, 1962 (1). This work was supported by U. S. Public Health Service grants HE-01275 and HE-05741.

$\dagger$ Postdoctoral fellow of the U. S. Public Health Service.

$\$$ Fellow of the Rockefeller Foundation. pathogenesis of other diseases in which there is "secondary" aldosteronism. The approach to this problem is complicated by the fact that pressor agents such as angiotensin influence the renal excretion of electrolytes in two ways, 1) by altering adrenal secretion of aldosterone and 2) by more immediate effects on the general circulation and on the kidney. Thus, while angiotensin stimulates both aldosterone output and sodium retention in normal subjects, sympathomimetic pressor agents may suppress aldosterone release and cause sodium diuresis, especially in sodium-depleted subjects, (7) and in idiopathic edema (8). Furthermore, immediate and impressive increases in sodium and water excretion occur in patients with arterial hypertension during administration of either angiotensin $(3,9,10)$ or norepinephrine (10) and in patients with cirrhosis given metaraminol ( $m$-hydroxynorephedrine) (11). Because the effects occur so rapidly in the latter two disorders, a change in aldosterone secretion is hardly responsible.

To define further possible interrelationships among pressor agents, sodium balance, and aldosterone secretion, in the present study we have compared the effects of equipressor amounts of angiotensin and norepinephrine on renal hemodynamics and on the clearance of electrolytes and water in both normal subjects and in patients with cirrhosis and ascites. Angiotensin was compared with norepinephrine because, to some extent, the role of hemodynamic change as a determinant of change in renal function may be assessed by comparing two agents having some similar actions on the circulation. Patients with cirrhosis and ascites were selected as a representative type of secondary aldosteronism because they secrete large amounts of the hormone and exhibit almost complete renal retention of sodium $(7,12)$. There- 
TABLE I

Effect of angiotensin and norepinephrine infusions on blood pressure, renal hemodynamics, and excretion of solutes and water during maintained water diuresis*

\begin{tabular}{|c|c|c|c|c|c|c|c|c|c|c|c|c|c|}
\hline $\begin{array}{l}\text { Patient, } \\
\text { date }\end{array}$ & Pressor agent & Dose & BP & $\mathrm{C}_{\text {In }}$ & СpaH & $\dot{\mathbf{v}}$ & $\mathrm{UNa}_{\mathrm{Na}} \mathrm{V}$ & UkV & UClV & $\begin{array}{l}\mathrm{C}_{\mathrm{Na}} / \\
\mathrm{C}_{\mathrm{In}}\end{array}$ & Uosm & Cosm & Снео \\
\hline & & $\mu g / \min$ & $m m \mathrm{Hg}$ & $\min _{\min }$ & $\min _{\min }$ & $\underset{m i n}{m l /}$ & $\underset{\min }{\mu E q /}$ & ${ }_{\min }^{\mu E q /}$ & ${ }_{\min }^{\mu E q /}$ & $\%$ & $\underset{m l}{\mu O s m /}$ & $\underset{m i n}{m l /}$ & $\min _{\min }$ \\
\hline \multicolumn{14}{|c|}{ Normal subjects on regular diet } \\
\hline B.U. & $\begin{array}{l}\text { Control } \\
\text { Antiotensin II }\end{array}$ & 3.8 & $\begin{array}{l}128 / 68 \\
162 / 105\end{array}$ & $\begin{array}{l}103 \\
102\end{array}$ & $\begin{array}{l}698 \\
245\end{array}$ & $\begin{array}{r}17.7 \\
8.7\end{array}$ & $\begin{array}{l}79 \\
24\end{array}$ & $\begin{array}{l}24 \\
32\end{array}$ & $\begin{array}{l}46 \\
17\end{array}$ & $\begin{array}{l}0.6 \\
0.2\end{array}$ & $\begin{array}{l}64 \\
86\end{array}$ & $\begin{array}{l}4.1 \\
2.6\end{array}$ & $\begin{array}{r}13.6 \\
6.1\end{array}$ \\
\hline S.U. & $\begin{array}{l}\text { Control } \\
\text { Norepinephrine }\end{array}$ & 18.8 & $\begin{array}{l}105 / 70 \\
150 / 88\end{array}$ & $\begin{array}{l}160 \\
142\end{array}$ & $\begin{array}{l}990 \\
497\end{array}$ & $\begin{array}{l}14.9 \\
11.0\end{array}$ & $\begin{array}{r}148 \\
65\end{array}$ & $\begin{array}{l}72 \\
41\end{array}$ & $\begin{array}{r}117 \\
58\end{array}$ & $\begin{array}{l}0.6 \\
0.3\end{array}$ & $\begin{array}{l}71 \\
61\end{array}$ & $\begin{array}{l}3.7 \\
2.4\end{array}$ & $\begin{array}{r}11.2 \\
8.6\end{array}$ \\
\hline $\begin{array}{l}\text { S.M. } \\
5 / 19 / 61\end{array}$ & $\begin{array}{l}\text { Control } \\
\text { Angiotensin II }\end{array}$ & 3.8 & $\begin{array}{l}120 / 70 \\
170 / 110\end{array}$ & $\begin{array}{l}124 \\
117\end{array}$ & $\begin{array}{l}613 \\
322\end{array}$ & $\begin{array}{r}13.9 \\
3.5\end{array}$ & $\begin{array}{r}151 \\
34\end{array}$ & $\begin{array}{l}54 \\
36\end{array}$ & $\begin{array}{l}67 \\
31\end{array}$ & $\begin{array}{l}0.8 \\
0.2\end{array}$ & $\begin{array}{r}59 \\
120\end{array}$ & $\begin{array}{l}2.9 \\
1.5\end{array}$ & $\begin{array}{r}11.0 \\
2.0\end{array}$ \\
\hline $\begin{array}{l}\text { S.M. } \\
5 / 10 / 61\end{array}$ & $\begin{array}{l}\text { Control } \\
\text { Norepinephrine }\end{array}$ & 18.8 & $\begin{array}{l}112 / 75 \\
170 / 98\end{array}$ & $\begin{array}{l}126 \\
111\end{array}$ & $\begin{array}{l}897 \\
388\end{array}$ & $\begin{array}{l}15.6 \\
12.0\end{array}$ & $\begin{array}{r}155 \\
77\end{array}$ & $\begin{array}{l}29 \\
17\end{array}$ & $\begin{array}{l}95 \\
49\end{array}$ & $\begin{array}{l}0.8 \\
0.5\end{array}$ & $\begin{array}{l}51 \\
49\end{array}$ & $\begin{array}{l}2.9 \\
1.1\end{array}$ & $\begin{array}{l}12.7 \\
10.9\end{array}$ \\
\hline \multicolumn{14}{|c|}{ Normal subjects on low-sodium diet } \\
\hline $\begin{array}{l}\text { S.M. } \\
5 / 29 / 61\end{array}$ & $\begin{array}{l}\text { Control } \\
\text { Angiotensin II }\end{array}$ & 3.8 & $\begin{array}{l}110 / 72 \\
160 / 112\end{array}$ & $\begin{array}{l}108 \\
104\end{array}$ & $\begin{array}{l}640 \\
279\end{array}$ & $\begin{array}{r}16.9 \\
3.2\end{array}$ & $\begin{array}{r}20 \\
2\end{array}$ & $\begin{array}{r}128 \\
47\end{array}$ & $\begin{array}{r}24.2 \\
5.4\end{array}$ & $\begin{array}{l}0.1 \\
0.0\end{array}$ & $\begin{array}{r}74 \\
155\end{array}$ & $\begin{array}{l}4.5 \\
1.8\end{array}$ & $\begin{array}{r}124 \\
1.4\end{array}$ \\
\hline S.M. $_{5 / 26 / 61}$ & $\begin{array}{l}\text { Control } \\
\text { Norepinephrine }\end{array}$ & 33.8 & $\begin{array}{l}105 / 60 \\
184 / 94\end{array}$ & $\begin{array}{l}129 \\
119\end{array}$ & $\begin{array}{l}630 \\
401\end{array}$ & $\begin{array}{r}16.5 \\
5.8\end{array}$ & $\begin{array}{r}24 \\
3\end{array}$ & $\begin{array}{l}95 \\
47\end{array}$ & $\begin{array}{r}18.6 \\
3.5\end{array}$ & $\begin{array}{l}0.1 \\
0.0\end{array}$ & $\begin{array}{r}70 \\
144\end{array}$ & $\begin{array}{l}4.2 \\
3.1\end{array}$ & $\begin{array}{r}12.3 \\
2.7\end{array}$ \\
\hline P.E. & $\begin{array}{l}\text { Control } \\
\text { Angiotensin II }\end{array}$ & 3.8 & $\begin{array}{l}94 / 64 \\
146 / 105\end{array}$ & $\begin{array}{l}123 \\
106\end{array}$ & $\begin{array}{l}592 \\
438\end{array}$ & $\begin{array}{r}15.7 \\
2.3\end{array}$ & $\begin{array}{r}46 \\
3\end{array}$ & $\begin{array}{l}35 \\
60\end{array}$ & $\begin{array}{r}15 \\
3\end{array}$ & $\begin{array}{l}0.3 \\
0.0\end{array}$ & $\begin{array}{r}57 \\
252\end{array}$ & $\begin{array}{l}3.3 \\
2.0\end{array}$ & $\begin{array}{r}12.4 \\
0.3\end{array}$ \\
\hline P.E. & $\begin{array}{l}\text { Control } \\
\text { Norepinephrine }\end{array}$ & 7.5 & $\begin{array}{l}100 / 64 \\
148 / 92\end{array}$ & $\begin{array}{l}179 \\
190\end{array}$ & $\begin{array}{l}751 \\
560\end{array}$ & $\begin{array}{l}16.7 \\
17.0\end{array}$ & $\begin{array}{l}63 \\
41\end{array}$ & $\begin{array}{l}37 \\
30\end{array}$ & $\begin{array}{l}43 \\
22\end{array}$ & $\begin{array}{l}0.2 \\
0.0\end{array}$ & $\begin{array}{l}56 \\
41\end{array}$ & $\begin{array}{l}3.2 \\
2.4\end{array}$ & $\begin{array}{l}13.5 \\
14.6\end{array}$ \\
\hline \multicolumn{14}{|c|}{ Normal subject after 2 weeks low-salt diet } \\
\hline P.E. & $\begin{array}{l}\text { Control } \\
\text { Angiotensin II }\end{array}$ & 3.8 & $\begin{array}{l}98 / 70 \\
155 / 110\end{array}$ & $\begin{array}{l}142 \\
140\end{array}$ & $\begin{array}{l}630 \\
310\end{array}$ & $\begin{array}{r}14.7 \\
1.1\end{array}$ & $\begin{array}{r}44 \\
2\end{array}$ & $\begin{array}{l}18 \\
\mathbf{3 0}\end{array}$ & $\begin{array}{r}20 \\
2\end{array}$ & $\begin{array}{l}0.2 \\
0.0\end{array}$ & $\begin{array}{r}35 \\
263\end{array}$ & $\begin{array}{l}1.8 \\
0.9\end{array}$ & $\begin{array}{r}12.9 \\
0.2\end{array}$ \\
\hline \multicolumn{14}{|c|}{ Normal subject after high-sodium diet plus desoxycorticosterone acetate } \\
\hline $\begin{array}{l}\text { S.M. } \\
6 / 13 / 61\end{array}$ & $\begin{array}{l}\text { Control } \\
\text { Angiotensin II }\end{array}$ & 3.8 & $\begin{array}{l}106 / 68 \\
162 / 106\end{array}$ & $\begin{array}{l}127 \\
106\end{array}$ & $\begin{array}{l}595 \\
258\end{array}$ & $\begin{array}{r}13.6 \\
3.5\end{array}$ & $\begin{array}{r}146 \\
32\end{array}$ & $\begin{array}{l}53 \\
55\end{array}$ & $\begin{array}{r}109 \\
40\end{array}$ & $\begin{array}{l}0.8 \\
0.2\end{array}$ & $\begin{array}{r}90 \\
179\end{array}$ & $\begin{array}{l}4.3 \\
2.7\end{array}$ & $\begin{array}{l}9.3 \\
0.8\end{array}$ \\
\hline \multicolumn{14}{|c|}{ Patients with cirrhosis with ascites (maintained on low-sodium diets) } \\
\hline \multirow[t]{2}{*}{$\begin{array}{l}\text { S.H. } \\
3 / 21 / 61\end{array}$} & $\begin{array}{l}\text { Control } \\
\text { Angiotensin II }\end{array}$ & 21 & $\begin{array}{l}105 / 62 \\
154 / 96\end{array}$ & $\begin{array}{l}126 \\
164\end{array}$ & $\begin{array}{l}709 \\
564\end{array}$ & $\begin{array}{r}7.2 \\
21.8\end{array}$ & $\begin{array}{r}20 \\
1,302\end{array}$ & $\begin{array}{l}129 \\
238\end{array}$ & $\begin{array}{r}84 \\
1,252\end{array}$ & $\begin{array}{l}0.1 \\
6.0\end{array}$ & $\begin{array}{l}129 \\
172\end{array}$ & $\begin{array}{r}3.4 \\
14.3\end{array}$ & $\begin{array}{l}3.8 \\
7.4\end{array}$ \\
\hline & $\begin{array}{l}\text { Recovery } \\
\text { Norepinephrine }\end{array}$ & 45 & $\begin{array}{r}94 / 60 \\
164 / 96\end{array}$ & $\begin{array}{l}121 \\
173\end{array}$ & $\begin{array}{l}546 \\
413\end{array}$ & $\begin{array}{r}4.0 \\
10.3\end{array}$ & $\begin{array}{l}15 \\
94\end{array}$ & $\begin{array}{l}69 \\
80\end{array}$ & $\begin{array}{r}41 \\
154\end{array}$ & $\begin{array}{l}0.1 \\
0.4\end{array}$ & $\begin{array}{l}183 \\
110\end{array}$ & $\begin{array}{l}2.6 \\
4.2\end{array}$ & $\begin{array}{l}1.4 \\
6.1\end{array}$ \\
\hline$\underset{4 / 3 / 61}{\text { M.A. }}$ & $\begin{array}{l}\text { Control } \\
\text { Angiotensin II }\end{array}$ & 10.5 & $\begin{array}{l}120 / 70 \\
158 / 88\end{array}$ & $\begin{array}{r}109 \\
95\end{array}$ & & $\begin{array}{r}7.8 \\
22.6\end{array}$ & $\begin{array}{r}37 \\
709\end{array}$ & $\begin{array}{r}96 \\
194\end{array}$ & $\begin{array}{r}40 \\
700\end{array}$ & $\begin{array}{l}0.3 \\
5.7\end{array}$ & $\begin{array}{l}71 \\
90\end{array}$ & $\begin{array}{l}2.1 \\
7.7\end{array}$ & $\begin{array}{l}5.7 \\
14.9\end{array}$ \\
\hline$\underset{4 / 6 / 61}{M . A . ~}$ & $\begin{array}{l}\text { Control } \\
\text { Norepinephrine }\end{array}$ & 15 & $\begin{array}{l}128 / 74 \\
160 / 88\end{array}$ & $\begin{array}{l}136 \\
237\end{array}$ & & $\begin{array}{r}7.2 \\
19.8\end{array}$ & $\begin{array}{r}17 \\
111\end{array}$ & $\begin{array}{l}41 \\
77\end{array}$ & $\begin{array}{l}12 \\
87\end{array}$ & $\begin{array}{l}0.1 \\
0.4\end{array}$ & $\begin{array}{l}\mathbf{5 5} \\
\mathbf{3 8}\end{array}$ & $\begin{array}{l}1.5 \\
2.9\end{array}$ & $\begin{array}{r}5.7 \\
16.9\end{array}$ \\
\hline$\underset{4 / 17 / 61}{F . E .}$ & $\begin{array}{l}\text { Control } \\
\text { Angiotensin II }\end{array}$ & 10.5 & $\begin{array}{l}140 / 80 \\
190 / 105\end{array}$ & $\begin{array}{l}90 \\
97\end{array}$ & $\begin{array}{l}757 \\
625\end{array}$ & $\begin{array}{r}5.5 \\
22.5\end{array}$ & $\begin{array}{r}7 \\
1,098\end{array}$ & $\begin{array}{r}65 \\
245\end{array}$ & 1,064 & $\begin{array}{l}0.1 \\
8.4\end{array}$ & $\begin{array}{r}78 \\
123\end{array}$ & $\begin{array}{r}1.6 \\
10.4\end{array}$ & $\begin{array}{r}3.9 \\
12.1\end{array}$ \\
\hline F.E. & $\begin{array}{l}\text { Control } \\
\text { Norepinephrine }\end{array}$ & 15 & $\begin{array}{l}120 / 65 \\
165 / 90\end{array}$ & $\begin{array}{l}71 \\
85\end{array}$ & $\begin{array}{l}609 \\
469\end{array}$ & $\begin{array}{l}10.0 \\
15.2\end{array}$ & $\begin{array}{r}3 \\
26\end{array}$ & $\begin{array}{l}60 \\
86\end{array}$ & $\begin{array}{r}2 \\
30\end{array}$ & $\begin{array}{l}0.0 \\
0.2\end{array}$ & $\begin{array}{l}36 \\
36\end{array}$ & $\begin{array}{l}1.3 \\
2.0\end{array}$ & $\begin{array}{r}8.7 \\
13.2\end{array}$ \\
\hline$\underset{4 / 19 / 61}{M . I}$ & $\begin{array}{l}\text { Control } \\
\text { Angiotensin II }\end{array}$ & 11.4 & $\begin{array}{l}100 / 68 \\
150 / 96\end{array}$ & $\begin{array}{l}62 \\
69\end{array}$ & $\begin{array}{l}375 \\
403\end{array}$ & $\begin{array}{r}6.4 \\
28.5\end{array}$ & $\begin{array}{r}45 \\
1,746\end{array}$ & $\begin{array}{l}27 \\
87\end{array}$ & $\begin{array}{r}18 \\
1,607\end{array}$ & $\begin{array}{r}0.5 \\
18.9\end{array}$ & $\begin{array}{r}90 \\
158\end{array}$ & $\begin{array}{r}2.1 \\
16.3\end{array}$ & $\begin{array}{r}4.3 \\
12.2\end{array}$ \\
\hline$\underset{4 / 27 / 61}{\text { M.I. }}$ & $\begin{array}{l}\text { Control } \\
\text { Norepinephrine }\end{array}$ & 15 & $\begin{array}{l}102 / 70 \\
132 / 86\end{array}$ & $\begin{array}{l}71 \\
76\end{array}$ & $\begin{array}{l}454 \\
386\end{array}$ & $\begin{array}{r}6.1 \\
12.4\end{array}$ & $\begin{array}{r}7 \\
65\end{array}$ & $\begin{array}{l}28 \\
40\end{array}$ & $\begin{array}{r}1 \\
54\end{array}$ & $\begin{array}{l}0.1 \\
0.6\end{array}$ & $\begin{array}{l}81 \\
70\end{array}$ & $\begin{array}{l}1.7 \\
3.1\end{array}$ & $\begin{array}{l}4.4 \\
9.3\end{array}$ \\
\hline S.C. & $\begin{array}{l}\text { Control } \\
\text { Angiotensin II }\end{array}$ & 7 & $\begin{array}{l}124 / 64 \\
196 / 94\end{array}$ & $\begin{array}{l}90 \\
88\end{array}$ & $\begin{array}{l}623 \\
456\end{array}$ & $\begin{array}{r}8.2 \\
33.2\end{array}$ & $\begin{array}{r}5 \\
1,879\end{array}$ & $\begin{array}{l}179 \\
382\end{array}$ & $\begin{array}{r}76 \\
1,873\end{array}$ & $\begin{array}{r}0.0 \\
16.2\end{array}$ & $\begin{array}{l}133 \\
178\end{array}$ & $\begin{array}{r}4.0 \\
20.8\end{array}$ & $\begin{array}{r}4.2 \\
12.4\end{array}$ \\
\hline $\begin{array}{l}\text { P.M. } \\
\text { 9/14/61 }\end{array}$ & $\begin{array}{l}\text { Control } \\
\text { Angiotensin II }\end{array}$ & 6 & $\begin{array}{l}106 / 74 \\
164 / 106\end{array}$ & $\begin{array}{l}110 \\
74\end{array}$ & $\begin{array}{l}680 \\
374\end{array}$ & $\begin{array}{r}7.6 \\
20.6\end{array}$ & $\begin{array}{r}64 \\
1,649\end{array}$ & $\begin{array}{r}88 \\
153\end{array}$ & $\begin{array}{r}56 \\
1,617\end{array}$ & $\begin{array}{r}0.4 \\
17.2\end{array}$ & $\begin{array}{l}107 \\
195\end{array}$ & $\begin{array}{r}3.0 \\
14.9\end{array}$ & $\begin{array}{l}4.6 \\
5.7\end{array}$ \\
\hline \multicolumn{14}{|c|}{ Effect of smaller doses of angiotensin during water diuresis in two patients with cirrhosis and ascites } \\
\hline $\begin{array}{l}\text { P.M. } \dagger \\
10 / 16 / 61\end{array}$ & $\begin{array}{l}\text { Control } \\
\text { Angiotensin II }\end{array}$ & 0.8 & $\begin{array}{l}100 / 70 \\
100 / 70\end{array}$ & $\begin{array}{l}33 \\
34\end{array}$ & $\begin{array}{l}386 \\
252\end{array}$ & $\begin{array}{l}3.6 \\
5.9\end{array}$ & $\underset{65}{2}$ & $\begin{array}{l}51 \\
92\end{array}$ & $\begin{array}{r}8 \\
116\end{array}$ & $\begin{array}{l}0.0 \\
1.4\end{array}$ & $\begin{array}{l}136 \\
136\end{array}$ & $\begin{array}{l}1.8 \\
3.0\end{array}$ & $\begin{array}{l}1.8 \\
2.9\end{array}$ \\
\hline S.C. $_{9 / 21 / 61}$ & $\begin{array}{l}\text { Control } \\
\text { Angiotensin II }\end{array}$ & 0.8 & $\begin{array}{l}112 / 60 \\
160 / 68\end{array}$ & $\begin{array}{l}84 \\
57\end{array}$ & $\begin{array}{l}612 \\
370\end{array}$ & $\begin{array}{r}7.9 \\
14.9\end{array}$ & $\begin{array}{r}13 \\
249\end{array}$ & $\begin{array}{l}172 \\
249\end{array}$ & $\begin{array}{r}17 \\
373\end{array}$ & $\begin{array}{l}0.1 \\
3.6\end{array}$ & $\begin{array}{l}138 \\
137\end{array}$ & $\begin{array}{l}3.5 \\
7.6\end{array}$ & $\begin{array}{l}2.4 \\
7.3\end{array}$ \\
\hline S.C. $/ 5 / 61$ & $\begin{array}{l}\text { Control } \\
\text { Angiotensin II }\end{array}$ & 0.4 & $\begin{array}{l}124 / 64 \\
138 / 64\end{array}$ & $\begin{array}{l}63 \\
57\end{array}$ & $\begin{array}{l}446 \\
364\end{array}$ & $\begin{array}{r}7.5 \\
10.3\end{array}$ & $\begin{array}{l}1.7 \\
3.4\end{array}$ & $\begin{array}{l}116 \\
124\end{array}$ & $\begin{array}{r}4 \\
29\end{array}$ & $\begin{array}{l}0.0 \\
0.1\end{array}$ & $\begin{array}{l}159 \\
157\end{array}$ & $\begin{array}{l}4.4 \\
5.8\end{array}$ & $\begin{array}{l}3.1 \\
4.5\end{array}$ \\
\hline
\end{tabular}

${ }^{*} \mathrm{BP}=$ blood pressure; $\mathrm{C}_{\mathrm{In}}=$ inulin clearance; $\mathrm{CPAH}_{1}=$ para-aminohippuric acid clearance; $\mathrm{V}=\mathrm{urine}$ flow; $\mathrm{UNaV}_{\mathrm{N}}=$ sodium excretion; $\mathrm{UKV}=$ potassium excretion; UClV $=$ chloride excretion; $\mathrm{CN}_{\mathrm{Na}} / \mathrm{C}_{\mathrm{In}}=$ sodium to inulin clearance ratio; Uosm $=$ urine osmolality; $\mathrm{Cosm}_{\mathrm{m}}=\mathrm{osmolar}$ clearance; and $\mathrm{C}_{2} \mathrm{O}=$ free-water clearance.

t Patient recently recovered from pneumonia with septicemia, azotemia, and hepatic decompensation. 
fore, these patients are likely to respond to angiotensin only by its circulatory actions or by a direct effect on the tubules, and not because it can elicit any further increase in aldosterone secretion.

\section{METHODS}

Twenty-two renal clearance studies were performed in four normal volunteers and in six patients with Laennec's cirrhosis who had massive ascites. These latter patients exhibited a general tendency for avid renal retention of sodium, as evidenced in their 24-hour rates of urinary sodium excretion, which, in all but one, averaged less than $5 \mathrm{mEq}$ per day. In addition, they exhibited marked oversecretion of aldosterone with values ranging from 250 to $2,000 \mu \mathrm{g}$ per day (normal range for this isotope-dilution method is from 50 to $250 \mu \mathrm{g}$ per day) $(1,10)$. Thorough investigation failed to reveal evidence of intrinsic cardiovascular or renal disease in any of the ten subjects.

All subjects were admitted to the research ward and maintained under conditions of controlled metabolic balance for at least 7 days. They received a constant dietary regimen containing either a normal sodium intake (4 to $8 \mathrm{~g} \mathrm{NaCl}$ per day) or a reduced intake (less than $0.875 \mathrm{~g} \mathrm{NaCl}$ per day). All subjects with cirrhosis and ascites were maintained on the low-sodium regimen, whereas normal subjects were studied before and after sodium deprivation. One additional study was carried out in a normal subject after daily administration of 10 $\mathrm{mg}$ desoxycorticosterone acetate intramuscularly together with a dietary intake of $16 \mathrm{~g}$ salt per day for 5 consecutive days. Distilled water was allowed ad libitum, and the 24-hour intake and urinary output were recorded. No medications other than occasional bedtime sedation with barbiturates were employed.

All experiments were performed at the same early morning hour with the subjects fasting, resting quietly in bed. All studies were carried out during a maintained water diuresis because changes in solute and free-water excretion in this state may reveal whether the site of action of an agent is in a proximal or a more distal segment of the nephron $(13,14)$. Water diuresis was induced by oral ingestion of $1,000 \mathrm{ml}$ of water during the hour before start of the infusions. It was maintained by iv administration of a 5\% dextrose solution at a rate, held constant by a motor-driven pump, at least $2 \mathrm{ml}$ per minute greater than the urine flow. Urine collections were made and discarded until a steady state of maximal urine flow was established. Sometimes it was necessary to wait for an hour after the beginning of the infusions for this to occur in patients with cirrhosis. During the control periods, the salt excretion of these patients was at a slightly higher rate than indicated by the balance studies, probably because water diuresis induces a mild saluresis (15). The presence of a steady state of maximal water diuresis was reconfirmed in three consecutive control clearance periods of approximately 10 minutes duration. With this approach, it was not likely that any increase in the urine flow or free-water clearance during experimental periods was simply the result of increasing water diuresis. Venous blood samples were collected at appropriate intervals through an indwelling needle. Urine was collected continuously via an indwelling catheter. Arterial blood pressure was measured at frequent intervals throughout the control and experimental periods with a standard cuff mercury sphygmomanometer. Upon completion of the control periods, either $l$-norepinephrine ${ }^{1}$ or valine 5 -angiotensin II amide ${ }^{2}$ was added to the infusion. The concentration of the pressor agent in the infusion was adjusted in accordance with previous experience (7), so that a sustained increment in the mean arterial pressure of about $35 \mathrm{~mm} \mathrm{Hg}$ was maintained.

The rate of glomerular filtration (GFR) and effective renal plasma flow (RPF) was measured by the administration of inulin and para-aminohippuric acid $(\mathrm{PAH})$. Adequate priming doses were given intravenously; then these substances were added to the $5 \%$ dextrose infusion fluid in amounts to maintain constant plasma concentrations of 25 and $2 \mathrm{mg}$ per $100 \mathrm{ml}$, respectively. PAH was added to the sustaining infusion immediately before use to avoid the depression in $\mathrm{PAH}$ extraction that can occur when $\mathrm{PAH}$ and dextrose are incubated together for several hours (16). Plasma and urine samples were analyzed for inulin, PAH, sodium and potassium, chloride, and total solute concentration by methods previously described (13). Mean arterial pressure was calculated by the formula: $\mathrm{MP}=3 / 5$ diastolic pressure $+2 / 5$ systolic pressure in millimeters $\mathrm{Hg}$. Osmolar and free-water clearance $\left(\mathrm{C}_{\mathrm{osm}}\right.$ and $\left.\mathrm{C}_{\mathrm{H}_{-\mathrm{O}} \mathrm{O}}\right)$ were defined as described by Smith (17) and by Wesson and Anslow (18).

\section{RESULTS}

The results of this study are summarized in $\mathrm{Ta}$ ble I. Data derived from Table I are also presented in Figures 1 to 3. In Table I, the findings of each clearance study are presented as mean values of three consecutive control periods and three consecutive experimental periods during which angiotensin or norepinephrine were given. Observed changes between control and experimental periods were abrupt, consistent in direction, and great enough to permit fair presentation by this method.

Results obtained during the first 20 to 30 minutes of infusion of the pressor agent are not included. Instead, this interval was utilized for determination and stabilization of pressor dosage, for circulatory readjustment, and for re-equilibration of inulin and PAH levels in plasma and urine. Owing to delay, i.e., the time required for urine to

\footnotetext{
${ }^{1}$ Levophed, Winthrop Laboratories, New York, N. Y.
} 2 Hypertensin, Ciba Pharmaceutical Co., Summit, N. J. 

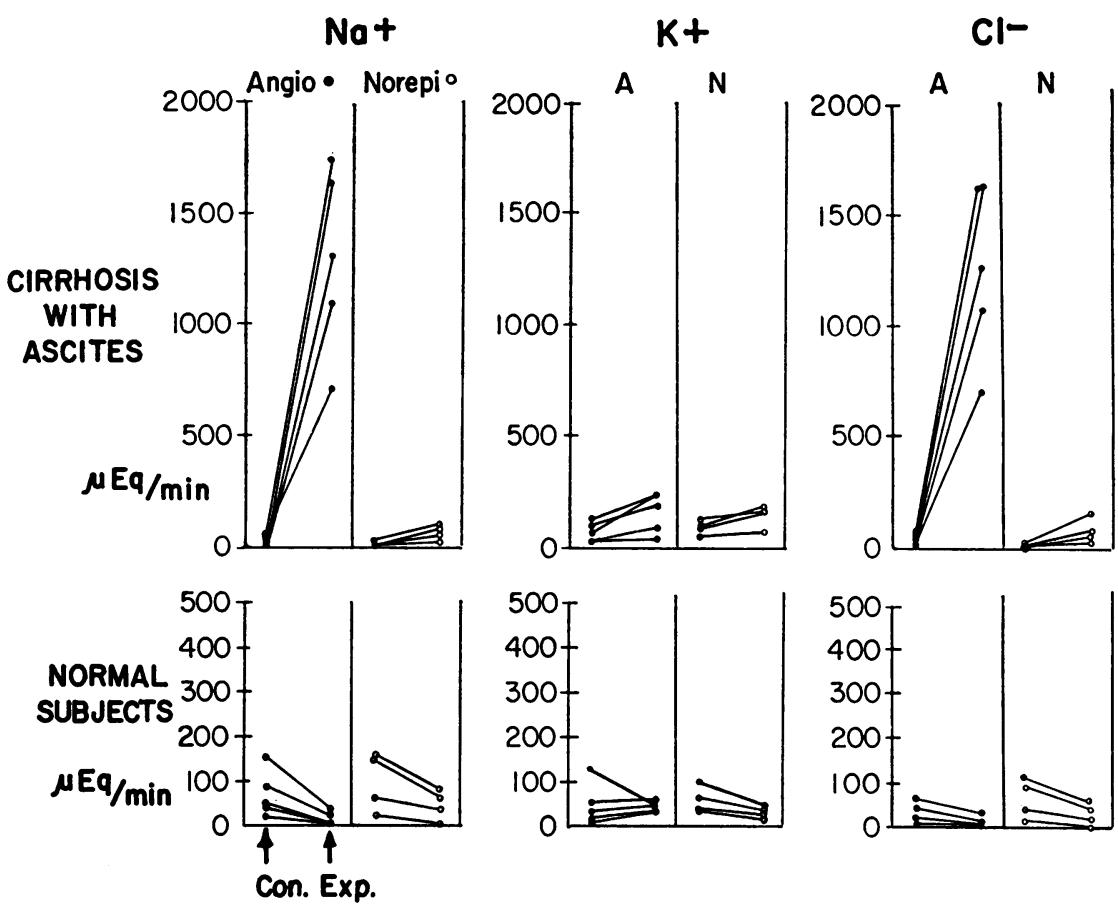

Fig. 1. EFFECT OF INFUSION OF EQUIPRESSOR AMOUNTS OF ANGIOTENSIN OR NOREPINEPHRINE ON THE EXCRETION OF ELECTROLYTES DURING MAINTAINED WATER DIUREsis. Average values for control and experimental periods are plotted and connected - for each patient. In normal subjects, both agents regularly produced sodium chloride retention accompanied by less consistent changes in potassium output. In sharp contrast, both agents regularly produced significant saluresis in patients with cirrhosis. The increased sodium chloride excretion of angiotensin was regularly far greater than that produced by norepinephrine.

flow from tubule to bladder, results from the first experimental period were probably modified by the presence of urine formed in the final control period. Exclusion of the results from this interval, therefore, seemed appropriate. Inspection of the data, however, indicated that in all experiments, changes observed after waiting 20 to 30 minutes were apparent in the first 10-minute experimental period. Plasma levels of sodium, potassium, chloride, and total solute are not presented because these values did not change appreciably once water diuresis had been achieved.

Effect of angiotensin II and norepinephrine on arterial blood pressure: dosage response considerations (Table I). Similar changes in mean arterial blood pressure were produced in both normal and cirrhotic subjects. The increases, which ranged from +35 to $+46 \mathrm{~mm} \mathrm{Hg}$, were achieved with an average dose of $3.8 \mu \mathrm{g}$ per minute of angiotensin in normal subjects. An average dose of
$11.1 \mu \mathrm{g}$ per minute (range, from 6 to $21 \mu \mathrm{g}$ per minute) was required for cirrhotic patients. This pronounced reduction in pressor response permitted administration of much larger doses in cirrhosis. The effect seemed unique for angiotensin, since similar amounts of norepinephrine were required for the same pressor response in both normal subjects and in patients with cirrhosisnormal subjects: average $19.7 \mu \mathrm{g}$ per minute (range, 7.5 to $33.8 \mu \mathrm{g}$ per minute); cirrhotics: average $22.5 \mu \mathrm{g}$ per minute (range, 15 to $45 \mu \mathrm{g}$ per minute). Every attempt was made to administer equipressor doses, but the data (Table I) reveal that angiotensin tended to have a slightly greater effect on the diastolic pressure, whereas norepinephrine tended to increase systolic pressure and the pulse pressure to a greater extent.

Effect on GFR, $R P F$, and filtration fraction. In normal subjects, angiotensin usually did not produce much change in the clearance of inulin. 
Slight reductions were observed in five out of six studies and an increase of $43 \mathrm{ml}$ per minute in the fifth, for a mean change in GFR of $+2 \mathrm{ml}$ per minute, or $+2 \%$ of control. This pressor agent regularly caused marked depression in $\mathrm{PAH}$ clearance, averaging $-319 \mathrm{ml}$ per minute, or $-51 \%$. Norepinephrine also produced slight, possibly insignificant, changes in GFR in normal suljjects (average change, $-8 \mathrm{ml}$ per minute, or $-5 \%$ of control) and marked reductions in $\mathrm{RPF}$ (mean, $-355 \mathrm{ml}$ per minute, or $-43 \%$ ). Largely because of changes in RPF, the mean filtration fraction values rose from 0.19 to 0.40 with angiotensin, and from 0.19 to 0.30 with norepinephrine.
In cirrhosis, angiotensin produced variable effects on GFR. The values increased in three and decreased in three of the six given full dosage. In three additional studies, smaller doses reduced the GFR in two and did not significantly alter the third. The full dose of angiotensin reduced RPF in all but one study, yielding an average fall of $-23 \%$ for the five. Similar reductions were observed in patients given smaller doses. In contrast, norepinephrine consistently increased GFR in four studies in cirrhosis. The mean value rose from 100 to $143 \mathrm{ml}$ per minute, a difference of $43 \mathrm{ml}$ per minute, or $+43 \%$ of the control value. Like angiotensin, norepinephrine uniformly depressed RPF in three studies, causing an average
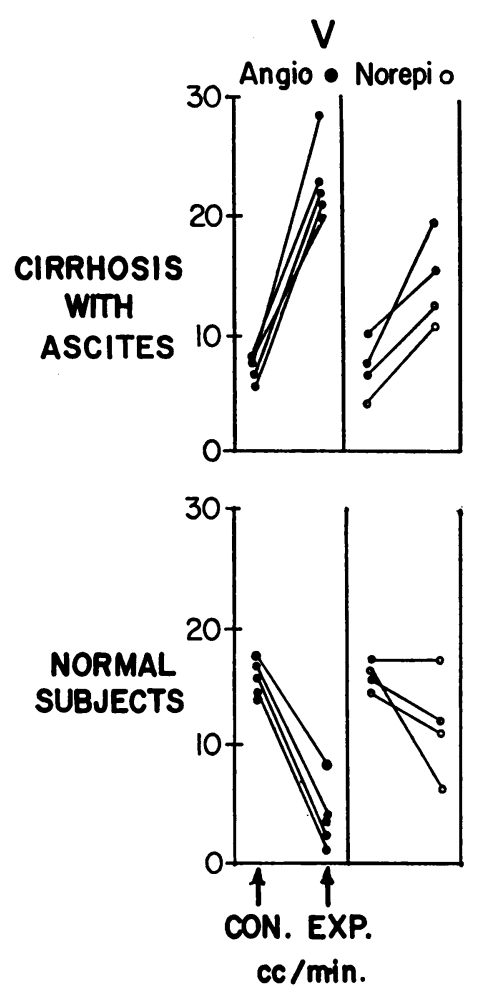
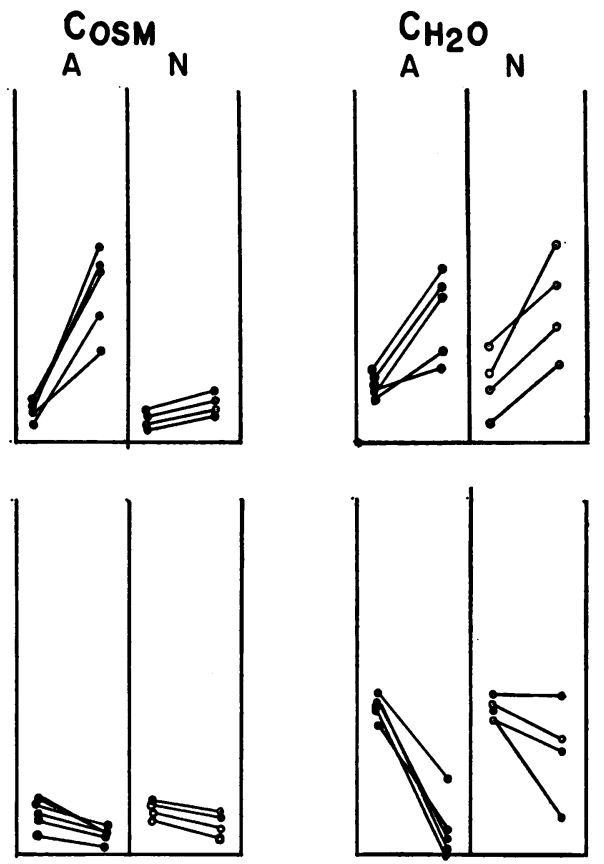

Fig. 2. EfFEct of ANgIOTENSIN AND NOREPINEPHRINe ON URINE FLOW (V) AND OSMOLAR AND FREE-WATER CLEARANCES $\left(\mathrm{C}_{\mathrm{osm}}, \mathrm{C}_{\mathrm{H}_{2} \mathrm{O}}\right)$. Average values from both the control and experimental periods are plotted and joined for an individual study. In normal subjects, both agents consistently reduced $\mathrm{V}, \mathrm{C}_{\mathrm{osm}}$, and $\mathrm{C}_{\mathrm{H}_{2} \mathrm{O}}$. Angiotensin produced slightly more solute and appreciably more water retention than did norepinephrine. In contrast, in cirrhosis both agents increased $\mathrm{V}, \mathrm{C}_{\mathrm{osm}}$, and $\mathrm{C}_{\mathrm{H}: \mathrm{O}}$. Angiotensin increased the $\mathrm{C}_{\mathrm{osm}}$ to a much greater extent than did norepinephrine. The increments in $\mathrm{C}_{\mathrm{H}_{2} \mathrm{O}}$ produced by both agents were similar. The very large increase in isosmotic solute excretion produced by angiotensin suggests that this agent acted to depress sodium reabsorption in the proximal tubule. The relatively small rise in $\mathrm{C}_{\mathrm{H}_{2} \mathrm{O}}$ noted with angictensin may mean that this agent also blocked sodium reabsorption in the more distal diluting segment(s) of the nephron. 


\section{CIRRHOSIS WITH ASCITES}

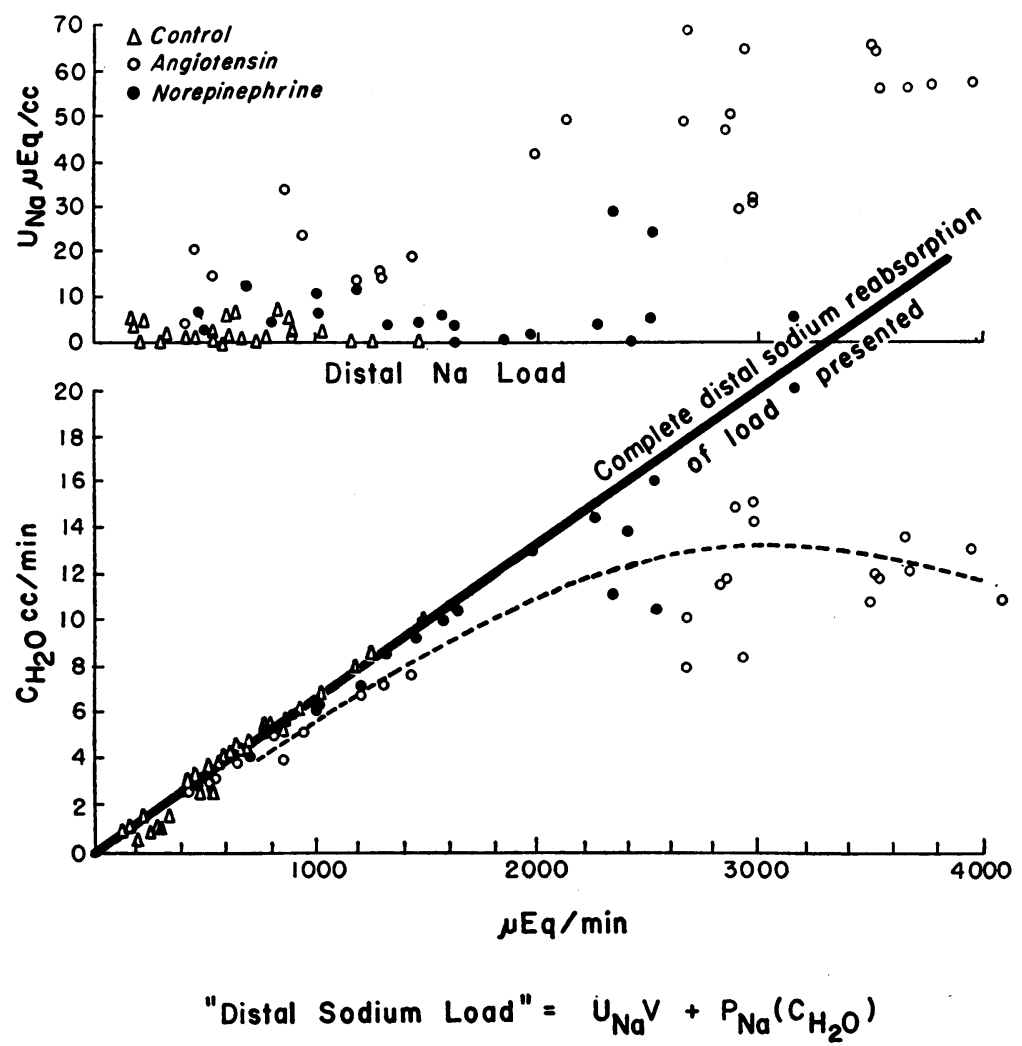

Fig. 3. Rate OF FReE-WATER Formation ( $\left.\mathrm{C}_{\mathrm{H}_{2} \mathrm{O}}\right)$ and URINARY CONCENTRATION OF SODIUM ( $U_{\mathrm{Na}}$ ) PLOTTED ON THE ORDINATES AGAINST THE AMOUNT OF SODIUM DELIVERED TO THE DISTAL DILUTING SEGMENT ("DISTAL SODIUM LOAD"). Control periods plotted from a number of experiments show that $\mathrm{C}_{\mathrm{H}_{2} \mathrm{O}}$ is directly related to the amount of sodium presented to the diluting segment. Norepinephrine (black dots) increases the distal sodium load, and $\mathrm{C}_{\mathrm{H}_{2} \mathrm{O}}$ rises at the same rate observed in the control periods, so that the urine tends to remain very dilute. In contrast, angiotensin increases distal solute load more than $\mathrm{C}_{\mathrm{H}_{2} \mathrm{O}}$, and the urine becomes more concentrated even when the induced increase in distal load is submaximal for angiotensin and is not so great as can occur with norepinephrine. The findings show that angiotensin generally tends to increase the concentration as well as the amount of sodium in the urine, and therefore, blocks sodium reabsorption in the distal diluting segment(s), as well as in the proximal nephron. (Data plotted from clearance studies of S.H., M.A., F.E., and S.C.).

fall of $-113 \mathrm{ml}$ per minute, or $-21 \%$ of control. Mean filtration fraction increased from 0.18 to 0.27 after norepinephrine and from 0.15 to 0.20 after angiotensin.

Effect on electrolyte $\left(\mathrm{Na}^{+}, \mathrm{K}^{+}, \mathrm{Cl}^{-}\right)$excretion. In normal subjects, angiotensin consistently produced significant reductions in the rate of sodium and chloride excretion and slight decreases in $\mathrm{K}^{+}$ output (Table I and Figure 1). These-responses were not modified by prior dietary sodium deprivation, or by expansion of the extracellular fluid achieved by prior administration of a sodium-retaining hormone to one subject on a high sodium diet. Norepinephrine, without exception, produced alterations in the electrolyte excretion similar in direction to those of angiotensin.

In sharp contrast to the effects observed in normal subjects, angiotensin consistently produced 
enormous increases in sodium and chloride excretion and smaller, but quite significant, increases in the potassium output of patients with cirrhosis and ascites. In some experiments, the rate of sodium excretion rose almost a hundredfold. The mean increments in electrolyte excretion in six clearance studies were: sodium $\left(\mathrm{U}_{\mathrm{Na}} \mathrm{V}\right),+1,367$ $\mu \mathrm{Eq}$ per minute; chloride $\left(\mathrm{U}_{\mathrm{Cl}} \mathrm{V}\right),+1,305 \mu \mathrm{Eq}$ per minute; and potassium $\left(\mathrm{U}_{\mathbf{K}} \mathrm{V}\right),+120 \mu \mathrm{Eq}$ per minute. Norepinephrine also increased electrolyte excretion in cirrhosis, but the increments were much smaller. Mean changes were: sodium, $+63 \mu \mathrm{Eq}$ per minute; chloride, $+67 \mu \mathrm{Eq}$ per minute; and potassium, $+21 \mu \mathrm{Eq}$ per minute.

Effect on clearance ratio $\left(\mathrm{C}_{\mathrm{Na}} / \mathrm{C}_{\mathrm{In}}\right)$ (Table $\mathrm{I}$ ). Angiotensin and norepinephrine always produced a slight fall in the $\mathrm{C}_{\mathrm{Na}} / \mathrm{C}_{\text {In }}$ ratio for normal subjects, but in each case the change was small. In contrast, angiotensin uniformly produced impressive increases in this ratio in patients with cirrhosis and ascites. This resulted from GFR remaining essentially unchanged, while sodium excretion increased greatly. The proportion of filtered sodium appearing in the urine increased from a mean control value of $0.23 \%$ to $12.1 \%$. Norepinephrine did not produce any significant change in the $\mathrm{C}_{\mathrm{Na}} / \mathrm{C}_{\mathrm{In}}$ ratio because the increases in sodium excretion were accompanied by increases in GFR.

Effect on urine flow, total solute, and $C_{\mathrm{H}_{2} \mathrm{O}}$ (Table I, Figure 2). Regardless of the state of sodium balance, in normal subjects, angiotensin caused reductions in the rate of urine flow that ranged from 9 to $13.7 \mathrm{ml}$ per minute, or from -51 to $-93 \%$ of the control values. The reductions were accounted for by a fall in both $\mathrm{C}_{\text {osm }}$ and $\mathrm{C}_{\mathrm{H}_{2} \mathrm{O}}$, especially the latter. $\mathrm{C}_{\text {osm }}$ fell by 0.9 to $2.7 \mathrm{ml}$ per minute, or 37 to $60 \%$ of the control value, while free-water output fell from 7.5 to $12.7 \mathrm{ml}$ per minute, or 55 to $98 \%$ of 226 to $755 \mu \mathrm{Osm}$ per minute. In all studies, there was a tendency for the urine osmolality $\left(\mathrm{U}_{\mathrm{osm}}\right)$ to rise during the antidiuresis produced by angiotensin.

Norepinephrine had much less tendency to reduce urine flow and $\mathrm{C}_{\mathrm{H}_{2} \mathrm{O}}$ in normal subjects than angiotensin, though solute excretion was reduced to the same extent. Urine flow actually increased slightly in one study, was reduced by only 3.6 and $3.9 \mathrm{ml}$ per minute in two others, and fell by 10.7 $\mathrm{ml}$ per minute in the fourth. In all of the studies, total solute excretion fell appreciably, dropping from 208 to $387 \mu$ Osm per minute. $\mathrm{C}_{\text {osm }}$ fell by from 0.8 to $1.8 \mathrm{ml}$ per minute, or from 25 to $62 \%$. $\mathrm{C}_{\mathrm{H}_{2} \mathrm{O}}$ increased slightly in one study, fell by 2.6 and $1.8 \mathrm{ml}$ per minute in two, and dropped $9.4 \mathrm{ml}$ per minute in one. In three of our experiments, the urine became slightly more dilute ( $U_{\text {osm }}$ fell) after norepinephrine.

In contrast to the results in normal subjects, administration of either pressor agent produced diuresis in patients with cirrhosis and ascites. The low control rates of urine flow and $\mathrm{C}_{\mathrm{H}_{2} \mathrm{O}}$ obtained during peak water diuresis reflect the well-known inability of these patients to excrete water normally. Angiotensin increased urine flow strikingly in every experiment: the mean increased from 7.1 to $24.9 \mathrm{ml}$ per minute. Total solute excretion rose dramatically from a mean of $732 \mu \mathrm{Osm}$ per minute to $3,830 \mu \mathrm{Osm}$ per minute. Mean $\mathrm{C}_{\text {osm }}$ increased from $2.7 \mathrm{ml}$ per minute to $14.1 \mathrm{ml}$ per minute; the average $\mathrm{C}_{\mathrm{H}_{2} \mathrm{O}}$ rose from 4.4 to $10.8 \mathrm{ml}$ per minute. $U_{o s m}$ increased slightly in each patient.

Norepinephrine administration increased both urine flow and total solute excretion, but to a lesser degree than angiotensin. Urine flow rose by an average of $7.6 \mathrm{ml}$ per minute, whereas the mean solute output increased by only $330 \mu \mathrm{Osm}$ per minute, so that the rise in osmolar clearance, $1.3 \mathrm{ml}$ per minute, was much smaller than that caused by angiotensin (11.4 ml per minute). Despite this lesser solute diuresis, norepinephrine increased $\mathrm{C}_{\mathrm{H}_{2} \mathrm{O}}$ as much as angiotensin $(+6.3 \mathrm{ml}$ per minute norepinephrine; $+6.4 \mathrm{ml}$ per minute angiotensin). As a result, the urine became more dilute during norepinephrine diuresis.

Effect of graded dosages on response to angiotensin in cirrhosis. Two patients with cirrhosis were studied repeatedly with different dosages of angiotensin (Table I). These data indicate that lower dose levels can produce the typical diuresis and saluresis of angiotensin with very little or no increase in arterial pressure. This possibly suggests that the pressor action of the peptide may not be essential for its effects on renal electrolyte and water transport. The magnitude of the response, however, depended on the angiotensin dose and was greatly increased by higher, i.e., overtly pressor, doses. 


\section{DISCUSSION}

The impressive and specific reduction in pressor responsiveness to angiotensin of patients with cirrhosis and ascites should be noted for two reasons. First of all, it resulted in the administration of much larger amounts of angiotensin than was possible in normal subjects. Secondly, it indicates that increased amounts of endogenous angiotensin could circulate in cirrhosis and account for the hyperaldosteronism and fluid retention without causing arterial hypertension. This reduced responsiveness to angiotensin might be similar to the tachyphylactic effect produced in normal dogs (19). Tachyphylaxis has not been found with prolonged infusion of angiotensin in normal man $(20,21)$.

From the data, it is apparent that both angiotensin and norepinephrine have dual effects on the renal excretion of sodium chloride. Both agents consistently produced salt retention in normal subjects, and, just as consistently, both caused impressive natriuresis in the patients with cirrhosis and ascites. Angiotensin was more potent than norepinephrine in its influences on sodium excretion, producing somewhat more sodium retention in normal subjects and much more saluresis in cirrhosis. Angiotensin also differed because it promoted somewhat more potassium excretion in cirrhosis and because it exhibited antidiuretic properties, causing relatively more water retention in the normal subjects and much less water diuresis per increment in sodium output in cirrhosis than did norepinephrine.

The most striking effects were the enormous increases in both sodium and chloride excretion produced by angiotensin in cirrhosis. These changes could not be correlated with changes in GFR, and therefore appear to have resulted from depressed tubular reabsorption of sodium. The effects were uniformly accompanied by considerable increases in the $\mathrm{C}_{\mathrm{Na}} / \mathrm{C}_{\mathrm{In}}$ ratio, so that the proportion of filtered sodium appearing in the urine rose to a mean value of over $10 \%$. At times, the increased sodium excretion was accompanied by a fall in GFR, making it even more unlikely that the saluresis resulted from an unmeasurable rise in GFR. ${ }^{3}$ Unlike angiotensin, norepinephrine

3 There is reason to believe that proximal sodium reabsorption does not operate near its maximal rate (17). caused a significant increase in the mean GFR in cirrhosis. Despite this increased filtration, it produced a much smaller increase in sodium excretion and caused no change in the $\mathrm{C}_{\mathrm{Na}} / \mathrm{C}_{\mathrm{In}}$ ratio. Therefore, while the saluresis produced by angiotensin in cirrhosis appeared to result from inhibition of sodium reabsorption by the renal tubule, that produced by norepinephrine could be related to an increase in GFR.

In contrast to the sodium diuresis produced by angiotensin and norepinephrine in cirrhosis, both agents regularly reduced the rate of sodium chloride excretion in normal subjects. These effects are subject to less definite interpretation than those observed in cirrhosis, since in the normal subjects there were no consistent, appreciable changes in the GFR, and decreases in the $\mathrm{C}_{\mathrm{Na}} / \mathrm{C}_{\mathrm{In}}$ ratio, although consistent, were small. But, at times, reduced sodium chloride excretion occurred with a slight increase in GFR. Thus, although the reduced sodium chloride excretion of normal subjects in response to both pressor agents might have resulted from a subtle reduction in GFR, the data possibly point towards an effect to increase tubular reabsorption.

The findings in normal subjects agree with previous work. Pressor or subpressor dosages of norepinephrine, epinephrine, or angiotonin produced sodium chloride retention that could not be accounted for by changes in GFR $(25,26)$. More recently, other groups (20-28) have reported that synthetic angiotensin II produces effects similar to angiotonin. It seems clear that, in normal sub-

Thus, a slight increase in filtered load probably would not begin to produce the predicted possible increase in the amount of filtrate reaching the distal nephron or the final urine. Slight reductions in GFR, however, might lead to a rather considerable drop in the amount of tubular fluid reaching the more distal nephron.

Actually, there is little information on the effect of increasing GFR per se on sodium and water excretion in patients with cirrhosis and ascites. Papper, however, in reviewing studies of 13 groups of investigators, could not correlate the presence of active ascites formation with any particular depression in either GFR or RBF (22). Dogs with caval occlusion and experimental ascites closely resemble these patients from the standpoint of renal electrolyte and aldosterone metabolism. Studies of these animals have shown that marked and sustained increases in GFR produced by a variety of technics (23, 24) do not overcome their state of nearly complete renal tubular sodium retention. 
jects, angiotensin regularly produces sodium chloride retention with either no change or a fall in GFR.

Thus, except for the diuresis produced by norepinephrine in cirrhosis, the ambivalent actions of both pressor agents on sodium excretion do not appear to be related to changes in GFR and might all be viewed as the result of altered tubular function. Only the effect of angiotensin in cirrhosis, however, was convincing enough in degree and nature to suggest to the authors that the major action of this agent was depressing the tubular reabsorption of sodium chloride.

The changes observed in electrolyte excretion did not seem to be definitely related to concurrent changes in RPF. Both angiotensin and norepinephrine consistently produced considerable renal ischemia, presumably largely by efferent (postglomerular) vasoconstriction. Similar findings have been reported by a number of investigators (25-28). RPF was reduced to a greater degree in normal subjects, perhaps because a certain amount of renal vasoconstriction was already present in patients with cirrhosis. Pre-existing increased renal resistance might have conditioned the paradoxical natriuretic response of these patients. Renal ischemia might modify the response to pressor agents by affecting tubular transport or by operating to change the functioning nephron population, but we obtained no evidence to support these possibilities.

Although both angiotensin and norepinephrine are potent vasoconstrictors, the changes that they induced in electrolyte excretion also appeared unrelated to any particular alteration in arterial blood pressure. Similar elevations of mean pressure produced opposite effects on sodium chloride excretion of normal subjects as compared with cirrhotic subjects, and the natriuresis produced by angiotensin in cirrhosis was much greater than that of equipressor dosages of norepinephrine.

While for the most part the effects on electrolyte and water excretion could not be explained by a change in renal hemodynamics or systemic arterial pressure, it is possible that a less welldefined intrarenal or extrarenal hemodynamic accompaniment of the induced vasoconstriction could be involved in the results. Thus, Selkurt (29) showed that in dogs whose renal arterial blood pressure was mechanically regulated, increases in mean pressure promoted sodium chloride excretion without altering GFR and RBF. Also, in patients with arterial hypertension, the degree of induced natriuresis produced by pressor agents appears directly related to the induced increments in systemic arterial pressure $(4,9,10)$. Differences between the hemodynamic actions of angiotensin and norepinephrine on various parts of the circulation $(30,31)$ might also be a basis for their discordant effects on electrolyte excretion.

In our studies of normal subjects, neither sodium depletion, with attendant physiologically increased aldosterone secretion, nor sodium accumulation produced by administration of a mineralocorticoid modified the sodium-retaining effect of pressor agents. In normal animals, however, angiotensin II and the related substances renin and angiotonin have produced ambivalent effects on the excretion of sodium chloride and water. Their administration caused diuresis in rabbits $(32,33)$ and rats $(34-36)$, and either diuresis or antidiuresis in dogs (37-39). Epinephrine and norepinephrine also can produce either effect $(32,40-45)$. In all these, as well as in our own experiments, the circumstances that dictate one effect rather than the other remain unclear.

Our interpretation of the present work-that angiotensin increases sodium excretion by an action on tubular transport rather than by an influence on GFR - gains additional support from two recent in vitro studies. Leyssac, Larsen, and Thaysen have reported that angiotensin inhibits sodium transport in kidney slices (46). Gertz and Gottschalk have found that relatively large doses of angiotensin reduce sodium reabsorption in the proximal tubule of the rat (47).

The present studies were made during maintained water diuresis to obtain information about the locus of action of angiotensin and norepinephrine in the nephron. The amount of free-water formation during water diuresis depends on the amount of filtered solute reaching a distal tubular site where it can be reabsorbed without isosmotic amounts of water, thereby generating free water for excretion. The formation of free water may be increased by increasing the amount of solute presented to the distal tubules. This has been demonstrated with agents that increase GFR, such as aminophylline (48), and with other maneuvers that deliver more solute distally, such as 
a high solute diet (49) or administration of nonresorbable agents with osmotic activity like mannitol (50). Conversely, procedures that either reduce GFR or augment proximal tubular reabsorption of sodium chloride may be expected to reduce free-water formation.

The effects of angiotensin and norepinephrine in normal subjects fall into the latter classification because both agents decreased $\mathrm{C}_{\mathrm{H}_{2} \mathrm{O}}$ and $\mathrm{C}_{\text {osm }}$ and urine flow when sodium excretion was reduced. The comparatively greater reduction in urine flow produced by angiotensin possibly was due to a relatively greater effect on either GFR or proximal sodium reabsorption.

On the other hand, the natriuresis produced by norepinephrine in patients with cirrhosis and ascites was accompanied by an increase in $\mathrm{C}_{\text {osm }}$, with a greater increase in $\mathrm{C}_{\mathrm{H}_{2} \mathrm{O}}$. These effects qualitatively and quantitatively resemble those produced by aminophylline in normal subjects (48) and by mannitol in both normal (51) and cirrhotic subjects (52). Since, as stated previously, these effects occurred without much change in $\mathrm{C}_{\mathrm{Na}} / \mathrm{C}_{\mathrm{In}}$, the major action of norepinephrine in cirrhosis appears to be an increase in the GFR, leading to delivery of more of the filtrate to the distal nephron.

Angiotensin produced far greater increases in sodium, chloride, and total solute clearances in cirrhosis than norepinephrine did. The solute diuresis was much greater than that produced by osmotic agents such as mannitol in this disorder $(21,52)$, and it equaled or exceeded that which occurs in hypertensive patients receiving angiotensin. ${ }^{4}$ The boost in $\mathrm{C}_{\text {osm }}$ produced by angiotensin in cirrhosis was greater than that usually achieved by chlorothiazide or meralluride (13, 48 ), drugs that are known to interfere with tubular reabsorption. This great potency has been repeatedly confirmed in prolonged infusion studies, some lasting 4 consecutive days $(1,19)$. The large increase in the isosmotic component of the urine $\left(\mathrm{C}_{\text {osm }}\right.$ mean rise, $11.4 \mathrm{ml}$ per min. $)$ suggests that the major effect of angiotensin was in-

\footnotetext{
4 The angiotensin natriuresis observed in patients with hypertension seems to differ in nature, because it may be associated with no change or increases in both GFR and RPF; also, it may be produced with other pressor agents, and it may be attenuated by sodium deprivation or by hypotensive therapy $(4,9,10,21)$.
}

hibition of proximal sodium chloride reabsorption. The resulting diversion of more tubular fluid distally may explain the increased free-water formation, $6.4 \mathrm{ml}$ per minute. If one assumes that the action of angiotensin is entirely on proximal reabsorption, it can thus be calculated that the mean rate of proximal reabsorption was inhibited to the remarkable extent of $17.8 \mathrm{ml}$ per minute.

Angiotensin generated relatively less free water per increment in solute clearance than norepinephrine. Three possible explanations for this are 1) the octapeptide has a mild vasopressin (antidiuretic hormone or ADH)-like action, or it induces ADH release, 2) it also retards distal reabsorption of sodium chloride, or 3 ) the sudden diversion of a large amount of proximal fluid distally, at least temporarily, exceeded the capacity for free-water formation by the diluting segment, so that a sodium reabsorptive maximal rate $\left(\mathrm{Tm}^{\mathrm{d}} \mathrm{Na}\right)$ (17) was reached. An $\mathrm{ADH}$-like action for angiotensin seems unlikely because a) free-water formation actually increased; b) chronic infusion of angiotensin does not lead to excessive water retention or oliguria: and $c$ ) in other acute clearance studies, angiotensin administration leads to a reduction in solute-free water clearance, $\mathrm{T}^{\mathrm{c}} \mathrm{H}_{2} \mathrm{O}$ (21).

The second possibility, that angiotensin inhibited distal reabsorption, is supported by the fact that urine became more concentrated during diuresis. In Figure 3, the rate of free-water formation $\left(\mathrm{C}_{\mathrm{H}_{2} \mathrm{O}}\right)$ and the urinary concentration of sodium $\left(\mathrm{U}_{\mathrm{Na}}\right)$ are both plotted on the ordinate against the concurrent amount of sodium delivered to the distal diluting segment, "distal sodium load." This value represents the minimal amount of sodium that must have been delivered beyond the proximal site of isosmotic reabsorption and then presented to the distal diluting segments of the nephron where free-water formation occurs. The quantity is derived from the sum of the amount of sodium consumed in freewater generation plus the amount simultaneously appearing in the urine. It is assumed that 1) all or nearly all urinary water is derived from the glomerular filtrate and 2) the tubular urine remains isosmotic up to a certain point in the nephron. Beyond this point, the sum of the processes for sodium reabsorption, with attend- 
ant anion, operate to dilute the urine and thereby account for increases in $\mathrm{C}_{\mathrm{H}_{2} \mathrm{O}}$.

Data (Figure 3) plotted from a number of clearances in cirrhosis show that free-water formation during the control periods was directly related to the amount of sodium presented to the diluting segment. Norepinephrine increased the distal sodium load, and $\mathrm{C}_{\mathrm{H}_{2} \mathrm{O}}$ continued to rise at the same rate as in the control periods, so that the urine remained very dilute. In contrast, angiotensin increased distal solute load more than $\mathrm{C}_{\mathrm{H}_{2} \mathrm{O}}$, and the urine became more concentrated even when the induced increase in distal load was submaximal for angiotensin and was not so great as that which could occur with norepinephrine. The plot illustrates that angiotensin tends to increase the concentration as well as the amount of sodium in the urine, and therefore, that it may block sodium reabsorption in the more distal diluting segments as well as in the proximal tubule.

The third possibility, that a $\mathrm{Tm}^{\mathrm{d}} \mathrm{Na}$ for sodium reabsorption was exceeded by the angiotensin natriuresis, is not supported by the data. If a distal $\mathrm{Tm}$ for sodium accounted for the failure of $\mathrm{C}_{\mathrm{H}_{2} \mathrm{O}}$ to continue rising as the distal sodium load was increased by angiotensin, then one would expect a similar phenomenon to occur with norepinephrine. Data from a number of clearance periods (Figure 3) demonstrate that norepinephrine caused more free-water formation than the maximum produced by angiotensin, even when distal sodium loads were of similar magnitude.

These new findings appear to complicate rather than clarify our understanding of a postulated renal-adrenal mechanism for normal control of sodium chloride balance in which angiotensin, liberated by the kidney, stimulates aldosterone secretion. This postulate has been supported by the evidence that angiotensin stimulates aldosterone release $(3,4,53,54)$. From the present study, however, it appears that angiotensin might have a more important role in regulation of the rate of proximal and possibly distal tubular sodium reabsorption. Could angiotensin be part of an intrarenal enzyme system and normally not enter the systemic circulation? If so, one could explain the confusing results of attempts to identify and quantitate the substance in the blood of normal subjects. On the other hand, the selective and per- sistent effects of angiotensin on adrenal cortical secretion (1) and the reduced pressor responsiveness of patients with cirrhosis indicate that increased circulating endogenous angiotensin could be a mechanism responsible for secondary aldosteronism.

It is therefore difficult to decide whether this action of angiotensin on renal sodium transport might have more physiological significance than its capacity to stimulate aldosterone secretion. The latter effect, however, is certainly not an exclusive one, since aldosterone secretion is also influenced by changes in plasma potassium level (55-58) and transiently by ACTH. For the present, this renal-adrenal interaction seems more complex than other familiar endocrine relationships.

\section{SUMMARY}

To study a possible renal-adrenal (angiotensinaldosterone) mechanism for the normal regulation of sodium balance, the effects of infusions of equipressor amounts of angiotensin and norepinephrine on renal hemodynamics and the clearances of electrolytes and water have been investigated in both normal subjects and in a representative type of secondary hyperaldosteronism, cirrhosis with ascites.

In cirrhosis with ascites, pressor responsiveness to angiotensin specifically was markedly reduced, suggesting that increased amounts of endogenous angiotensin could be circulating to account for this form of hyperaldosteronism without causing arterial hypertension.

Angiotensin and norepinephrine exhibited dual effects on sodium chloride and water excretion. Both agents promoted sodium chloride and water retention in normal subjects; both caused natriuresis and diuresis in cirrhosis. Angiotensin was much more potent than norepinephrine, producing somewhat more sodium retention in normal subjects and very much more saluresis in cirrhosis.

The renal pressor substance also produced slightly more potassium excretion in cirrhosis and exhibited antidiuretic properties, causing relatively more water retention in the normal subjects and much less water diuresis per given natriuresis in cirrhosis than did norepinephrine.

The circumstances that dictate whether angio- 
tensin or norepinephrine will elicit sodium retention rather than sodium diuresis remain unexplained. The ambivalent action of these agents did not appear to have been determined by a particular change in arterial pressure or by the presence of increased aldosterone secretion.

In normal subjects, changes in glomerular filtration rate (GFR) were usually slight and inconsistent in direction, so that it seemed possible that the effects of both angiotensin and norepinephrine on electrolyte excretion might result from altered tubular function.

In cirrhosis, angiotensin consistently increased sodium chloride excretion to a much greater extent than did norepinephrine. The proportion of filtered sodium excreted $\left(\mathrm{C}_{\mathrm{Na}} / \mathrm{C}_{\mathrm{In}}\right)$ increased from a mean value of 0.2 to $12.1 \%$ with the GFR remaining relatively constant, demonstrating that angiotensin depressed renal tubular reabsorption of sodium chloride. In contrast, the milder natriuresis and the considerable water diuresis produced by norepinephrine in these patients with cirrhosis were often associated with an increased filtration rate.

In cirrhosis, clearance data during water diuresis indicate that angiotensin markedly depressed the proximal isosmotic reabsorption of sodium chloride. The data also suggest that angiotensin blocked sodium reabsorption in a distal portion of the nephron at the site of freewater formation.

It therefore seems clear that angiotensin, by either a direct action on tubule cells or as a result of strategic, but ill-defined, intrarenal vasoconstriction can have a profound effect on renal tubular processes for sodium reabsorption.

The striking effects of angiotensin on sodium transport raise the possibility that this substance normally plays an intrarenal role in regulation of sodium balance. The magnitude of the observed effects indicate that such an action might be of greater significance than its other effects on arterial pressure and on aldosterone release.

\section{ACKNOWLEDGMENT}

We are deeply indebted to Dr. C. H. Sullivan of Ciba Pharmaceutical Products, Inc., Summit, N. J., for the generous supply of angiotensin.

\section{REFERENCES}

1. Laragh, J. H., P. J. Cannon, R. P. Ames, A. M. Sicinski, C. J. Bentzel, and J. I. Meltzer. Angiotensin II and renal sodium transport: natriuresis and diuresis in patients with cirrhosis and ascites. J. clin. Invest. 1962, 41, 1375.

2. Laragh, J. H., S. U. Ulick, V. Januszewicz, Q. B. Deming, W. G. Kelly, and S. Lieberman. Aldosterone secretion and primary and malignant hypertension. J. clin. Invest. 1960, 39, 1091.

3. Laragh, J. H., M. Angers, W. G. Kelly, and S. Lieberman. Hypotensive agents and pressor substances. The effect of epinephrine, norepinephrine, angiotensin II, and others on the secretory rate of aldosterone in man. J. Amer. med. Ass. 1960, 174, 234.

4. Genest, J., P. Biron, E. Koiw, W. Nowacynski, M. Chreitien, and R. Boucher. Adrenocortical hormones in human hypertension and their relation to angiotensin. Circulat. Res. 1961, 9, 775.

5. Laragh, J. H. The role of aldosterone in man. Evidence for regulation of electrolyte balance and arterial pressure by a renal-adrenal system which may be involved in malignant hypertension. J. Amer. med. Ass. 1960, 174, 293.

6. Kahn, J. R., L. P. Skeggs, Jr., N. P. Shumway, and $P$. E. Wisenbaugh. The assay of hypertensin from the arterial blood of normotensive and hypertensive human beings. J. exp. Med. 1952, 95, 523.

7. Laragh, J. H. Interrelationships between angiotensin, norepinephrine, epinephrine, aldosterone secretion, and electrolyte metabolism in man. Circulation 1962, 25, 203.

8. Greenough, W. B., III, E. H. Sonnenblick, V. Januszewicz, and J. H. Laragh. Correction of hyperaldosteronism and of massive fluid retention of unknown cause by sympathomimetic agents. Amer. J. Med. 1962, 33, 603.

9. Dustan, H., C. Nijenson, and A. C. Corcoran. Natriuretic-diuretic effect of angiotonin in essential hypertension (abstract). J. clin. Invest. 1955, 34, 931.

10. Brown, J. J., and W. S. Peart. The effect of angiotensin on urine flow and electrolyte excretion in hypertensive patients. Clin. Sci. 1962, 22, 1.

11. Gornel, D. L., R. G. Lancestremere, S. Papper, and L. M. Lowenstein. Acute changes in renal excretion of water and solute in patients with Laennec's cirrhosis, induced by the administration of the pressor amine meteraminol. J. clin. Invest. $1962,41,594$.

12. Ulick, S., J. H. Laragh, and S. Lieberman. The isolation of a urinary metabolite of aldosterone and its use to measure the rate of secretion of aldosterone by the adrenal cortex of man. Trans. Ass. Amer. Phycns 1958, 71, 225. 
13. Heinemann, H. O., F. E. Demartini, and J. H. Laragh. The effect of chlorothiazide on renal excretion of electrolytes and free water. Amer. J. Med. 1959, 26, 853.

14. Sonnenblick, E. H., P. J. Cannon, and J. H. Laragh. The nature of the action of intravenous aldosterone: evidence for a role of the hormone in urinary dilution. J. clin. Invest. 1961, 40, 903.

15. Birchard, W. H., T. E. Prout, T. F. Williams, and J. D. Rosenbaum. Diuretic responses to oral and intravenous water loads in patients with hepatic cirrhosis. J. Lab. clin. Med. 1956, 48, 26.

16. Baldwin, D. S., G. E. Schreiner, E. S. Breed, L. G. Wesson, Jr., and M. H. Maxwell. Depression of apparent $p$-aminohippurate extraction ratio by glucose. J. clin. Invest. 1950, 29, 614.

17. Smith, H. W. Principles of Renal Physiology, New York, Oxford University Press, 1956.

18. Wesson, L. G., Jr., and W. P. Anslow, Jr. Effect of osmotic and mercurial diuresis on simultaneous water diuresis. Amer. J. Physiol. 1952, 170, 255

19. Gross, F., and K. D. Bock. Some contributions to the pharmacology of synthetic angiotensin. Circulation 1962, 25, 193.

20. Finnerty, F. A., Jr. Hemodynamics of angiotensin in man. Circulation 1962, 25, 255.

21. Laragh, J. H., P. J. Cannon, R. P. Ames, and A. M. Sicinski. Unpublished observations.

22. Papper, S. The role of the kidney in Laennec's cirrhosis of the liver. Medicine (Baltimore) 1958, 37, 299.

28. Davis, J. O., and D. S. Howell. Mechanisms of fluid and electrolyte retention in experimental preparation in dogs. II. With thoracic inferior vena cava constriction. Circulat. Res. 1953, 1, 171.

24. Davis, J. O., D. S. Howell, and R. E. Hyatt. Effect of chronic Pitressin administration on electrolyte excretion in normal dogs and in dogs with experimental ascites. Endocrinology 1954, 55, 409.

25. Smythe, C. McC., J. F. Nickel, and S. E. Bradley. The effect of epinephrine (USP) $l$-epinephrine and $l$-norepinephrine on glomerular filtration rate, renal plasma flow, and the urinary excretion of sodium, potassium, and water in normal man. $\mathrm{J}$. clin. Invest. 1952, 31, 499.

26. Nickel, J. F., C. McC. Smythe, E. M. Papper, and S. E. Bradley. A study of the mode of action of the adrenal medullary hormones on sodium, potassium and water excretion in man. J. clin. Invest. 1954, 33, 1687.

27. Bock, K. D., H. Dengler, H. J. Krecke, and G. Reichel. Untersuchungen über die Wirkung von synthetishen Hypertensin II auf Elektrolythaushalt. Nierenfunktion und Kreislauf beim Menschen. Klin. Wschr. 1958, 36, 808.

28. McQueen, E. G., and R. B. I. Morrison. The effects of synthetic angiotensin and noradrenaline on blood pressure and renal function. Brit. Heart J. 1961, 23, 1.

29. Selkurt, E. E. Effect of pulse pressure and mean arterial pressure modification on renal hemodynamics and electrolyte and water excretion. Circulation 1951, 4, 541.

30. Haddy, F. J., J. I. Molnar, C. W. Borden, and E. C. Texter, Jr. Comparison of direct effects of angiotensin and other vasoactive agents on small and large blood vessels in several vascular beds. Circulation 1962, 25, 239.

31. Rose, J. C., P. A. Kot, J. N. Cohn, E. D. Freis, and G. E. Eckert. Comparison of effects of angiotensin and norepinephrine on pulmonary circulation, systemic arteries and veins, and systemic vascular capacity in the dog. Circulation 1962, $25,247$.

32. Hughes-Jones, N. C., G. W. Pickering, L. H. Sanderson, H. Scarborough, and J. Vandenbroucke. The nature of the action of renin and hypertensin on renal function in the rabbit. J. Physiol. (Lond.) 1949, 109, 288

33. Brandt, J. L., and J. G. Gruhn. Effect of renin on proteinuria and $\mathrm{PAH}$ clearance at low plasma levels. Amer. J. Physiol. 1948, 153, 458.

34. Masson, G. M. C., A. C. Corcoran, and I. H. Page. Some effects of chronic treatment of rats with renin. Amer. J. Physiol. 1950, 16, 379.

35. Sellers, A. L., S. Smith III, H. C. Goodman, and J. Marmorston. Effects of renin on excretion of sodium, chloride and water in the rat. Amer. J. Physiol. 1951, 166, 619.

36. Croxatto, H., L. Barnafi, L. Camazon, and V. Parra. Some endocrine factors in the polyuric acition of renin. Endocrinology 1954, 54, 239.

37. Whitney, J., S. Smith III, J. Marmorston, H. Goodman, and A. Sellers. Antidiuretic effect of renin in the dog. Amer. J. Physiol. 1954, 176, 419.

38. Corcoran, A. C., and F. del Greco. Mechanisms of renin diuresis in dogs. Fed. Proc. 1955, 14, 31.

39. Gross, F., and H. Turrian. Pharmacology of hypertensin and synthetic analogues in Polypeptides which Affect Smooth Muscle and Blood Vessels. New York, Pergamon Press, 1960, p. 137.

40. Richards, A. N., and O. H. Plant. The action of minute doses of adrenalin and pituitrin on the kidney. Amer. J. Physiol. 1922, 59, 191.

41. Winton, F. R. The control of the glomerular pressure by vascular changes within the isolated mammalian kidney demonstrated by the action of adrenaline. J. Physiol. (Lond.) 1931, 53, 151.

42. Toth, L. A. The effects of epinephrine on urine excretion in dogs. Amer. J. Physiol. 1937, 119, 140.

43. Gaunt, R., M. Liling, and M. Cordsen. Adrenal medulla in water diuresis and water intoxication. Endocrinology 1945, 37, 136.

44. Eversole, W. J., F. A. Giere, and M. H. Rock. Effects of adrenal medullary hormones on renal 
excretion of water and electrolytes. Amer. J. Physiol. 1952, 170, 24.

45. Blake, W. D. Some effects of single, subcutaneous injections of adrenal medullary hormones on renal excretion of water and electrolytes in the dog. Amer. J. Physiol. 1955, 181, 417.

46. Leyssac, P. P., U. V. Lassen, and J. H. Thaysen. Inhibition of sodium transport in isolated renal tissue by angiotensin. Biochim. biophys. Acta (Amst.) 1961, 48, 602.

47. Gertz, H. K., and C. W. Gottschalk. Personal communication.

48. Goldstein, M. H., M. F. Levitt, A. D. Hauser, and D. Polimeros. Effect of meralluride on solute and water excretion in hydrated man: comments on site of action. J. clin. Invest. 1961, 40, 731.

49. Kleeman, C. R., F. H. Epstein, and C. White. The effect of variations in solute excretion and glomerular filtration on water diuresis. J. clin. Invest. 1956, 35, 749.

50. Orloff, J., H. N. Wagner, Jr., and D. G. Davidson. The effect of variations in solute excretion and vasopressin dosage on the excretion of water in the dog. J. clin. Invest. 1958, 37, 458.

51. Williams, T. F., W. Hollander, Jr., M. B. Strauss, E. C. Rossmeisl, and R. McLean. Mechanism of increased renal sodium excretion following mannitol infusion in man. $J$. clin. Invest. 1955, 34, 595.
52. Schedl, H. P., and F. C. Bartter. An explanation for an experimental correction of the abnormal water diuresis in cirrhosis. J. clin. Invest. 1960, 39, 248.

53. Carpenter, C. C. J., J. O. Davis, and C. R. Ayers. Relation of renin, angiotensin II and experimental renal hypertension to aldosterone secretion. $\mathrm{J}$. clin. Invest. 1961, 40, 2026.

54. Mulrow, P. J., W. F. Ganong, G. Cera, and A. Kuljian. The nature of the aldosterone-stimulating factor in dog kidneys. J. clin. Invest. 1962, 41, 505.

55. Laragh, J. H., and H. C. Stoerk. A study of the mechanism of secretion of the sodium-retaining hormone (aldosterone). J. clin. Invest. 1957, 36, 383.

56. Moran, W. H., Jr., J. C. Rosenberg, and B. Zimmermann. The regulation of aldosterone output: significance of potassium ion. Surg. Forum, 1959, 9, 120.

57. Blair-West, J. R., J. P. Coghlan, D. A. Denton, J. R. Goding, J. A. Munro, R. E. Peterson, and M. Wintour. Humoral stimulation of adrenal cortical secretion. J. clin. Invest. 1962, 41, 1606.

58. Davis, J. O., J. Urquhart, and J. T. Higgins, Jr. The effects of alterations of plasma sodium and potassium concentration on aldosterone secretion. J. clin. Invest. 1963, 42, 597. 